\title{
PEMBINAAN BUDAYA LITERASI BERBASIS ANDROID UNTUK KEMAHIRAN BAHASA INGGRIS DAN KESANTUNAN BERBAHASA
}

\author{
Yunisa Oktavia $^{* 1}$, Emil Eka Putra ${ }^{* 2}$, Mesri Silalahi*3 \\ ${ }^{1,2}$ Program Studi Sastra Inggris, Fakultas Ilmu Sosial dan Humaniora, Universitas Putera Batam; \\ Jalan R. Soeprapto Tembesi Batam, (0778) 7001000 \\ ${ }^{3}$ Program Studi Sistem Informasi, Fakultas Teknik dan Komputer, Universitas Putera Batam \\ *E-mail: yunisaoctavia@gmail.com
}

\begin{abstract}
Literacy culture needs to be intensified so that the public does not become prey and does not accept deceptive news that can damage the single diversity order ika. The following are discussions for the purpose of this service activity to be carried out. (1) Communities are more receptive to certain news so that conflict and hostility can easily occur between them. (2) The community does not understand literacy in order to be able to think critically and wisely. (3) The Seroja community has not yet developed android-based literacy to improve English proficiency. (4) Daily conversations need to be reflected. The method of applying this service is a service team that transfers material and practices using Android for five meetings from December 2, 2018 to February 24, 2019. A supporting team that discusses the issue of literacy culture is based on Android, using Android to use and use English applications. for English success skills. In addition, talking about important politeness in everyday life. The results of services for this community are people who are critical, change their mindset, have proficiency, English, and improve understanding of the community of intelligent vocabulary and characters. Therefore, this service is important to enhance the Android-based literacy culture to improve English proficiency and politeness through the character education of the Seroja community in Sagulung District, Batam City.
\end{abstract}

Keyword: Android, Character Education, Culture of Literacy, English Language Proficiency, Language Politeness.

\begin{abstract}
Abstrak
Budaya literasi perlu digiatkan kepada masyarakat agar tidak terjerumus dan tidak menerima berita hoax yang dapat merusak tatanan bhinneka tunggal ika. Berikut permasalahan sehingga kegiatan pengabdian ini urgensi untuk dilaksanakan. (1) Masyarakat lebih cenderung menerima berita tertentu sehingga sangat mudah terjadi pertikaian dan pemusuhan di antara mereka. (2) Masyarakat belum mengetahui tentang literasi agar mampu berpikir secara kritis dan bijak. (3) Masyarakat Seroja belum membudayakan literasi berbasis android untuk meningkatkan kemahiran bahasa Inggris. (4) Percakapan sehari-hari perlu mencerminkan kesantunan berbahasa melalui pendidikan karakter. Metode pelaksanaan kegiatan pengabdian ini adalah tim pengabdi secara bergantian menyampaikan materi dan praktik penggunaan android selama lima kali pertemuan pada tanggal 2 Desember 2018 sampai 24 Februari 2019. Tim pengabdi menyampaikan pentingnya budaya literasi berbasis android, mengoptimalkan penggunaan android untuk mengunduh dan mendayagunakan aplikasi bahasa Inggris untuk kemahiran berbahasa Inggris. Selain itu, menyampaikan pentingnya kesantunan berbahasa dalam kehidupan sehari-hari. Hasil pengabdian kepada masyarakat ini masyarakat bersikap kritis, mengubah pola pikir, memiliki kemahiran berbahasa Inggris dan bertambahnya pemahaman kosakata serta masyarakat berkarakter cerdas. Oleh karena itu, kegiatan pengabdian ini penting dilaksanakan untuk mengoptimalkan budaya literasi berbasis android untuk meningkatkan kemahiran berbahasa Inggris dan kesantunan berbahasa melalui pendidikan karakter masyarakat Seroja Kecamatan Sagulung Kota Batam.
\end{abstract}

Kata Kunci: Android, Budaya Literasi, Kemahiran Bahasa Inggris, Kesantunan Berbahasa, Pendidikan Karakter. 


\section{PENDAHULUAN}

Budaya literasi sebagai bentuk kegiatan untuk menerima, menganalisis, memverifikasi, serta menyadur suatu informasi yang didapat secara bijak oleh masyarakat. Budaya literasi ini tidak hanya dibutuhkan oleh kelompok akademik, tetapi juga bagi masyarakat awam dalam memfilter sejumlah berita maupun informasi tertentu yang belum jelas kebenarannya. Kegiatan pengabdian kepada masyarakat ini memiliki peran penting dalam menangkal berita hoax di tengah-tengah kehidupan masyarakat khususnya pemukiman yang ditempati oleh masyarakat yang strata pendidikannya menengah ke bawah dari berbagai daerah. Masyarakat dapat hidup berdampingan tanpa memandang suku dan RAS. Oleh karena itu, pada masa ini pemerintah pun beserta jajarannya sangat menggiatkan budaya literasi bagi masyarakat agar tidak terjerumus dan tidak menerima berita hoax yang dapat merusak tatanan bhinneka tunggal ika.

Urgensi pelaksanaan kegiatan pengabdian ini adalah berita hoax kebanyakan mangandung isu SARA bercampur budaya malas membaca [1] (Akhyar, 2017). Kemalasan masyarakat dalam membaca tersebut membuat bahaya hoax semakin besar dan bisa jadi mengancam kehidupan manusia. Oleh karena itu dibutuhkan suatu sikap yang cerdas dan bijaksana, agar bahaya hoax tersebut bisa ditanggulangi sedini mungkin. Melalui kegiatan pengabdian ini, masyarakat harus cerdas dan bijak dalam menangkal berita hoax yang sangat meresahkan warga masyarakat. Masyarakat diajak untuk berliterasi yang dampak memanfaatkan teknologi digital yang sangat memfasilatasi kebutuhan masyarakat saat sekarang.

Selain itu, berdasarkan hasil survei dan observasi pada tanggal 24 Juni 2018, masyarakat di Seroja RW 16 Dapur 12 Kecamatan Sagulung Kota Batam lebih cenderung menerima berita-berita maupun informasi tertentu sehingga sangat mudah terjadi pertikaian dan pemusuhan di antara mereka. Hal ini bisa menyebabkan terjadinya kehidupan yang tidak rukun antarsesama warga. Pada hakikatnya, kehidupan bermasyarakat dan bertetangga harus damai dan saling menghormati satu sama lain. Namun, informasi yang mereka dapat tersebut diterima secara mentah-mentah tanpa dianalisis terlebih dahulu. Berdasarkan analisis situasi tersebut, kegiatan pembinaan ini membantu masyarakat Seroja agar terhindar dari perpecahan dan saling menjunjung tinggi perdamaian dalam kehidupan bermasyarakat.

Dalam kegiatan pengabdian kepada masyarakat ini, tim pengabdi berupaya untuk memerikan pembinaan budaya literasi berbasis android ini untuk meningkatkan kemahiran berbahasa Inggris dan kesantunan berbahasa masyarakat. Bahasa yang digunakan masyarakat dalam berinteraksi sehari-hari juga memerlukan kesantunan berbahasa. Jangan sampai salah kata atau salah bahasa antara anggota masyarakat yang satu dengan yang lain juga menimbulkan konflik di antara mereka. Masyarakat harus mampu memikirkan apa bahasa yang patut disampaikan saat berkomunikasi. Dengan demikian, kesantunan berbahasa juga berdampingan dalam budaya literasi. Pendayagunaan android ini sangat membantu masyarakat dalam memahami kosakata yang menggunakan bahasa Inggris, listening, grammar. Android sangat mudah dijumpai ditengah masyarakat karena pada umumnya masyarakat sudah memiliki media komunikasi berupa android. Namun, masyarakat setempat belum mengetahui aplikasi tersebut serta kegunaannya secara intensif. Tim pengabdi akan menyampaikan materi pengabdian saat di lapangan nanti bahwa android yang dimiliki sangat berdampak positif bagi kesejahteraan mereka. android tidak hanya membawa dampak negatif berupa candu bagi penggunanya bahkan dapat mengganggu kesehatan masyarakat.

Selain itu, pentingnya kegiatan pengabdian ini agar masyarakat harus mengetahui seluk-beluk berbahasa Inggris secara umum. Hal ini menjadi acuan bagi Tim Pengabdi untuk memerikan pembinaan kepada masyarakat untuk merealisasikan kemahiran berbahasa Inggris kepada masyarakat tersebut. Kemahiran berbahaasa Inggris ini bertujuan agar masyarakat tidak terjebak dengan kata-kata atau bahasa asing yang pada akhirnya dapat merugikan masyarakat setempat. Apalagi pada saat sekarang, baik itu diberita maupun kata-kata yang disampaikan orang lain cenderung menggunakan campur dua bahasa antara bahasa Indonesia dan bahasa Inggris. Hal ini bisa menyebabkan miss communication bagi masyarakat jika di antara mereka ada yang tidak memahami bahasa Inggris secara umum.

Positifnya, literasi berbasis android sangat dekat dengan dunia maya mampu menghubungkan individu dengan individu lain tanpa batas. Manusia memiliki akses yang lebih luas dan mampu mendapatkan informasi secara lebih efisien dan meningkatnya peluang bisnis e-commerce, lahirnya 
lapangan kerja baru berbasis media digital, dan pengembangan kemampuan literasi tanpa menegasikan teks berbasis cetak. Dalam berliterasi, masyarakat juga harus mampu bertutur secara lisan maupun tulisan tanpa mengesampingkan kesantunan berbahasa. Masyarakat menjadi contoh bagi generasi keturunannya dan orang-orang di sekitar dalam melestarikan budaya bangsa dari segi kesantunan berbahasa. Masyarakat harus mengetahui dan melestarikan "maaf, tolong, dan terima kasih". Bahkan di kalangan instansi tertentu pun sudah mulai jarang membudayakan "maaf, tolong, dan terima kasih". Padahal itu merupakan menunjukkan kualitas diri seseorang dalam kesantunan berbahasa yang sudah mulai punah. Seolah-olah hal itu menjadi suatu momok merasa harga diri seseorang rendah. Namun, sebaliknya hal itu menunjukkan jati diri dan entitas kita sebagai bangsa Indonesia yang berbudaya dan beradab. Dari fenomena itulah, tim pengabdi memiliki tanggung jawab sebagai akademisi dalam membudayakan kesantunan berbahasa di tengah-tengah kehidupan masyarakat. Kesantunan berbahasa pada masa kini dianggap hal yang diremehkan dan tidak bermutu.

Jika kesantunan berbahasa sudah diterapkan oleh masyarakat, maka akan menumbuhkan pendidikan karakter bagi anak bangsa khususnya masyarakat. Karakter menjadi ciri khas bangsa Indonesia karena Kota Batam sebagai Tanah Melayu yang terkenal berbudaya dan beradab. Pendidikan karakter itu meliputi dari segi tenggang rasa, menghormati keberagaman suku, agama, dan ras, mengutamakan kepentingan masyarakat, santun, jujur, dan bertanggung jawab.

[2] Muslich (2011, p. 80) menjabarkan nilai-nilai pendidikan karakter berdasarkan filosofis kehidupan bangsa, yaitu Pancasila. Oleh karena itu, terdapat lima pilar karakter berbasis nilai luhur bangsa Indonesia sebagai berikut. (a) Transendensi, merupakan suatu sikap untuk menyadari bahwa manusia merupakan ciptaan Tuhan Yang Maha Esa. Darinya akan memunculkan penghambaan sematamata pada Tuhan-nya yang Esa. (b) Humanisasi adalah sikap menyadari bahwa manusia pada hakikatnya setara di mata Tuhan, yang membedakannya hanya ilmu dan ketakwaan. Manusia diciptakan sebagai subjek yang memiliki potensi. (c) Kebhinekaan adalah kesadaran akan ada sekian banyak perbedaan di dunia. Akan tetapi, mampu mengambil kesamaan untuk menumbuhkan kekuatan. (d) Liberasi adalah pembebasan atas penindasan sesama manusia. Oleh karena itu, tidak dibenarkan penjajahan manusia oleh manusia. (e) Keadilan merupakan kunci kesejahteraan. Adil tidak berarti sama, tetapi proporsional.

Kegiatan pengabdian kepada masyarakat ini dilaksanakan di Seroja Dapur 12 Kecamatan Sagulung Kota Batam tanggal 2 Desember 2018 sampai dengan 24 Februari 2019. Pada pelaksanaan pertemuan pertama, tim pengabdi menyampaikan pentingnya budaya literasi berbasis digital. Pada pertemuan kedua, tim pengabdi akan menyampaikan materi optimalisasi budaya linguistik berbasis android untuk meningkatkan kemahiran berbahasa Inggris dan kesantunan berbahasa masyarakat Seroja Dapur 12 RW 16 Kecamatan Sagulung Kota Batam.

Pentingnya kegiatan pembinaan ini berdasarkan pada permasalahan yang ditemui oleh tim pengabdi. Kegiatan pengabdian ini memiliki urgensi untuk memerikan perubahan dan peningkatan tentang kemahiran berbahasa Inggris kepada masyarakat. Termasuk pada pengoptimalisasikan android sebagai sarana yang efektif bagi masyarakat. Selain itu, kegiatan pengabdian ini untuk mengubah karakter masyarakat menjadi pribadi yang lebih baik lagi. Berikut dijabarkan secara spesifikasi terhadap pelaksanaan urgensi kegiatan pengabdian ini. Pertama, masyarakat belum mengetahui tentang literasi padahal literasi sebagai pondasi dasar bagi masyarakat untuk bisa mengetahui, menerima, menyadur, dan menganalisis tentang suatu perkara atau informasi yang belum jelas kebenarannya. Dalam kegiatan pengabdian ini, masyarakat akan diberikan informasi dan dibina bagaimana caranya memanfaatkan, membudayakan, dan mengoptimalkan literasi untuk kemaslahatan pergaulan hidup dalam bermasyarakat.

Kedua, masyarakat gampang terpengaruh akan berita hoax. Oleh karena itu, dalam kegiatan pengabdian ini tim pengabdi berupaya untuk mampu merasionalisasikan berita-berita yang tersebar di tengah-tengah kehidupan masyarakat agar mampu memfilter terlbih dahulu sebelum disebarkan kepada yang lain. Masyarakat harus cerdas dan bijak dalam hal tersebut.

Ketiga, pada umumnya masyarakat Seroja tersebut sudah cakap dengan teknologi. Masyarakat sudah menggunakan teknologi berbasis android atau digital sebagai sarana berkomunikasi secara efektif. Namun, pada umumnya masyarakat setempat belum memanfaatkan budaya literasi digital sebagaimana mestinya. Bahkan masyarakat sangat gampang terpengaruh dengan hal maupun kebijakaan-kebijakan 
pemerintah setempat maupun daerah yang masih dalam tahap sosialisasi. Oleh karena itu, tim pengabdi akan mengajak dan mengoptimalkan penggunaan literasi digital bagi masyarakat. Apalagi dunia digital lebih cenderung menggunakan bahasa asing, yaitu bahasa Inggris. Jadi, masyarakat juga perlu mendapatkan materi pembinaan untuk meningkatkan kemahiran berbahasa Inggris secara fasih dan cakap. Dalam kajian literasi digital ini mengajak masyarakat untuk mampu memanfaatkan, mengakses, dan menerima informasi dari gawai baik secara daring maupun luring. Semenjak gawai hadir di tengah-tengah kehidupan masyarakat, banyak memiliki dampak kepada masyarakat.

Keempat, berdasarkan informasi maupun berita yang diperoleh oleh masyarakat banyak terdapat berita-berita yang menggunakan kosakata bahasa Inggris sehingga masyarakat sulit untuk menafsirkan apa maksud yang sebenarnya. Dalam kegiatan pembinaan ini, tim pengabdi sekaligus menyampaikan dan memerikan materi seputar kecakapan dan kemahiran dalam berbahasa Inggris. Masyarakat akan sangat terbantu dalam kegiatan sehari-hari termasuk pada dunia kerja mereka yang pada umumnya kerja serabutan mampu memahami dan menggunakan bahasa Inggris di tengah arus sibernitas bahasa.

Kelima, pada saat observasi ke awal ke lokasi pengabdian, tim pengabdi mendengar percakapan sesama warga masyarakat Seroja dalam pergaulan sehari-hari masih menggunakan bahasa yang belum santun. Masih terdapat masyarakat menggunakan bahasa yang tidak santun kepada orang tuanya yang menurut mereka sudah menggunakan prinsip kesantunan berbahasa. Dari kejadian tersebut, tim pengabdi memiliki tanggung jawab yang besar dalam menyampaikan prinsip kesantunan berbahasa agar memiliki nilai rasa positif.

Keenam, pendayagunaan literasi berbasis android ini dapat memerikan dampak positif kepada masyarakat agar masyarakat terhindar dari hal-hal yang provokatif maupun penipuan online yang marak terjadi. Melalui kegiatan pengabdian ini, masyarakat juga mampu bersikap kritis dan mampu mengubah pola pikir. Hal ini akan membawa keutungan kepada masyarakat sehingga masyarakat terhindar dari halhal yang dapat menggangu dan merusak kelangsungan hidup mereka. Di samping itu, kehidupan masyarakat juga terjaga dengan aman dan kondusif.

Berdasarkan hasil penelitian yang dilakukan oleh [3] Tirado-Morueta, Aguaded-Gómez, \& Hernando-Gómez (2018) bahwa literasi berbasis Android memerikan dampak yang positif bagi masyarakat. Literasi digital dikaitkan dengan tingkat yang paling dasar akses dan penggunaan internet sehingga dapat memoderasi rintangan yang berasal dari usia dan sumber daya sosial ekonomi.

Sesuai dengan masalah yang ditemukan saat observasi ke lapangan tersebut, pengabdian ini memerikan peran positif bagi kehidupan masyarakat. Masyarakat dapat berdedikasi dalam pendidikan karakter. Hasil penelitian yang dilaksanakan oleh [4] Oktavia dan Hulu (2017) bahwa pendidikan karakter sangat berperan dalam mendidik setiap lapisan masyaraat dalam kegiatan sehari-hari. Mahasiswa sebagai masyarakat belajar harus memiliki etika dan karakter yang budiman. Pendidikan karakter bertujuan untuk meningkatkan mutu penyelenggaraan dan hasil pendidikan yang mengarah pada pencapaian pembentukan karakter dan akhlak mulia seseorang secara utuh, terpadu dan seimbang. Melalui pendidikan karakter diharapkan seseorang secara mandiri meningkatkan dan menggunakan pengetahuannya, serta mengkajinya. Masyarakat juga terbiasa dalam mendayagunakan literasi berbasis Android untuk kebaikan dan kesejahteraan hidup mereka. Masyarakat dalam memanfaatkan Android ini juga mampu membuka wirausaha secara online. Apalagi masyarakat sekitar juga memiliki kreativitas yang dapat mengahsilkan pundi-pundi rupiah. Hal ini juga dapat menumbuhkan dan membangkitkan perekonomian mastarakat se-tempat karena mendayagunakan Android serta mahir dalam berbahasa Inggris.

Saat ini banyak terdapat aplikasi-aplikasi belajar Bahasa Inggris berbasis android yang dapat digunakan oleh masyarakat. Diantaranya Duolingo: Belajar Inggris, Hello English: Learn English, Kamusku Inggris Indonesia, Indonesian-English Translator, English Conversation Practice, Kamus Offline Lengkap, English Vocabulary Daily, Learn English, Speak English dan lain-lain.

Selanjutnya, target positif dalam kegiatan pengabdian ini adalah jika masyarakat sudah mahir berbahasa Inggris mendayagunakan Android selama kegiatan pengabdian yang direncanakan satu tahun ini juga memerikan peluang besar masyarakat untuk membuka usaha bimbingan belajar bahasa Inggris atau pusat-pusat education centre. Hal ini juga dapat mewujudkan visi misi pemerintah dan sesuai dengan terget pengabdian kepada masyarakat untuk dapat menumbuhkan usaha kreatif bagi masyarakat sehingga 
meningkatkan kesejahteraan masyarakat. Selain itu, masyarakat juga mampu secara mandiri dalam menggunakan dan mengembangkan aplikasi android sesuai dengan tuntutan zaman.

Kegiatan pengabdian kepada masyarakat ini, memerlukan dukungan semua pihak mulai peran dari masyarakat itu sendiri, jajaran RT/RW, termasuk ranah akademisi untuk mencapai indikator tujuan ranah pendidikan. Oleh karena itu, kegiatan pengabdian kepada masyarakat membawa manfaat yang sangat kontibutif bagi peserta pengabdian. Bahwasanya kegiatan pengabdian untuk mengoptimalkan budaya literasi berbasis android untuk meningkatkan kemahiran berbahasa Inggris dan kesantunan berbahasa masyarakat melalui pendidikan berkarakter.

\section{METODE}

Metode pelaksanaan kegiatan sebagai berikut. (a) Tim pengabdi memberikan konsep pemahaman materi dengan menggunakan metode experience based learning tentang pentingnya literasi berbasis literasi digital, materi untuk meningkatkan kemahiran berbahasa Inggris, dan materi tentang kesantunan berbahasa bagi masyarakat. (b) Tim pengabdi secara bergantian selama lima kali pertemuan untuk menyampaikan materi dan berdiskusi bersama masyarakat tentang topik yang sudah ditetapkan serta mengelompokkan masyarakat berdasarkan usianya agar penyampaian materi tepat sasaran berbasis android. (c) Tim pengabdi terdiri atas lima orang yang memiliki multidisiplin ilmu dalam lintas prodi. Tim pengabdi memiliki kolaborasi untuk menunjang kelancaran kegiatan pengabdian ini. Ketua pengabdi yang memaparkan materi meningkatkan dan mengembangkan budaya literasi serta kesantunan berbahasa melalui pendidikan karakter kepada masyarakat. Anggota pengabdi kedua memaparkan materi kemahiran berbahasa Inggris, sedangkan pengabdi ketiga memaparkan cara mahir berbahasa Inggris dengan mendayagunakan android. (d) Dua orang mahasiswa sebagai anggota tim pengabdi berperan dalam menyampaikan materi pengabdian. Mahasiswa dari prodi bahasa Inggris bertanggung jawab dengan topik basic english, sedangkan mahasiswa dari prodi sistem informasi menyampaikan materi pendayagunaan android untuk meningkatkan dan mengembangkan kemahiran berbahasa Inggris masyarakat. (d) Tim pengabdi mendayagunakan literasi digital agar menarik perhatian masyarakat sehingga tujuan pengabdian kepada masyarakat ini tepat sasaran. (e) Tim pengabdi mengevaluasi dan memonitoring materi dan dampaknya kepada masyarakat. (f) Mendayagunakan aplikasi-aplikasi belajar Bahasa Inggris berbasis android kepada masyarakat.(g) Tim pengabdi membuka ajang diskusi seputar topik pembinaan optimalisasi budaya literasi berbasis android untuk meningkatkan kemahiran berbahasa Inggris dan kesantunan berbahasa melalui pendidikan berkarakter masyarakat.

\section{HASIL DAN PEMBAHASAN}

Kegiatan pengabdian ini dilaksanakan selama lima kali pertemuan yang dimulai pada tanggal 2 Desember 2018 sampai 24 Februari 2019. Tema kegiatan pengabdian ini adalah Pembinaan Budaya Literasi Berbasis Android untuk Kemahiran Bahasa Inggris dan Kesantunan Berbahasa Melalui Pendidikan Berkarakter Masyarakat Dapur 12 Batam. Sasaran kegiatan pengabdian ini adalah ibu-ibu rumah tangga yang memiliki kesibukkan dan fokus pada kegiatan rumah tangga termasuk mendidik anakanak mereka di rumah. Kegiatan pengabdian ini bertujuan untuk mengoptimalisasikan budaya literasi berbasis android untuk meningkatkan kemahiran berbahasa Inggris dan kesantunan berbahasa melalui pendidikan berkarakter masyarakat. Oleh karena itu, selama pengabdian berlangsung, kegiatan ini disambut antusias oleh ibu-ibu di Seroja Dapur 12 Kota Batam yang dibuktikan dengan keseriusan mereka dalam mengikuti kegiatan ini dari awal sampai akhir. Selain itu, ibu-ibu tersebut juga aktif bertanya jawab untuk bisa didiskusikan bersama tim pengabdi yang terdiri atas lima orang.

Kegiatan pengabdian kepada masyarakat ini sebagai ajang untuk sharing dan saling berbagi informasi kepada peserta pengabdian bahwa budaya literasi itu sangat penting. Peserta pengabdian tidak boleh terhasut dan diprovokasi oleh informasi yang belum tentu kebenarannya sehingga tidak bisa dipertanggungjawabkan. Di samping itu, kegiatan berliterasi untuk menghindari terjadinya kesalahpahaman sesama anggota masyarakat berbau SARA dan politisasi tidak sehat. Masyarakat harus 
mampu memfilter hoax yang sangat marak terjadi pada masa kini. Selain itu, peserta pengabdian juga diajak agak mampu berliterasi digital.

Literasi digital pada masa kini sebagai kajian penting yang harus dibudayakan oleh ibu-ibu peserta pengabdian. Hal ini bertujuan agar ibu tersebut tidak bisa dibohongi oleh anak-anak mereka yang lebih melek teknologi. Kegiatan pengabdian ini mengajak ibu-ibu tersebut agar menyeleraskan dan lebih peduli dengan kecanggihan dunia digital sekarang. Literasi digital berbasis android ini, masyarakat dituntut untuk mampu berkomunikasi secara santun baik dalam media tulis, lisan, maupun update status pada media sosial. Kesantunan berbahasa tersebut menunjukkan kualitas diri seseorang yang berbudaya dan beradab.

Selain itu, kegiatan pengabdian ini mendayagunakan literasi digital berbasis android agar masyarakat Seroja memiliki kemahiran berbahasa Inggris. Masyarakat sebagai ibu-ibu muda yang menjadi teladan bagi anak-anaknya harus mampu berbahasa Inggris dalam keseharian walaupun tidak sempurna. Namun, hal ini menjadi sangat urgen bagi masa sekarang agar ibu rumah tangga di sana tidak terkecoh dengan setiap kegiatan dan gerak-gerik yang dilakukan oleh anaknya. Kegiatan ini menjadi tindakan sebagai bentuk pengawasan ibu-ibu terhadap anak-anaknya baik di lingkungan rumah, bermain, dan sekolah. Selain itu, apabila ibu-ibu rumah tangga tersebut mahir berbahasa Inggris khusunya sebagai bentuk bahasa percakapan keseharian dapat memotivasi anak-anak mereka agara lebih mahir lagi berbahasa Inggris secara efektif.

Pada kegiatan pengabdian yang dilaksanakan setiap dua minggu sekali ini juga menyampaikan bahwa pendidikan karakter menjadi bagian sangat penting dan tidak dilepaskan dalam kehidupan berumah tangga, bermasyarakat, maupun lingkungan pendidikan. Pendidikan karakter menjadi modal awal untuk bisa bersosialisasi di mana pun kita beraa. Hal ini bisa menunjukkan sikap yang beretika, bahasa yang santun, dan amanah dalam setiap kegiatan yang dilaksanakan. Pendidikan karakter juga menunjukkan kesantunan berbahasa. Kesantunan berbahasa perlu disampaikan karena bahasa pada umumnya dipakai oleh orang tua kepada anak-anak mereka juga belum menunjukkan bahasa yang santun dan ramah sehingga anak memiliki kecenderungan bahasa yang diperoleh dalam kehidupan berumah tangga.

Pada pertemuan pertama dilaksanakan pada tanggal 2 Desember 2018, kegiatan pengabdian ini dihadiri sebanyak 23 orang peserta pengabdian. Sebagai tahap awal, tim pengabdi membuka kegiatan sekaligus perkenalan dengan anggota masyarakat di Seroja Dapur 12 Kota Batam. Kegiatan pengabdian kegiatan dilaksanakan mulai pukul 14.00-16.30 WIB. Pada saat pertemuan awal, tim pengabdi beserta peserta pengabdian kepada masyarakat saling berkenalan dan temu ramah. Selanjutnya, disampaikan materi pentingnya berliterasi bagi ibu-ibu rumah tangga. Literasi sebagai kegiatan yang sangat positif sembari mendukung program pemerintah dalam berliterasi khususnya literasi digital. Literasi digital dengan maksud dalam pendayagunakan android yang dimiliki oleh ibu-ibu agar dapat digunakan degan tepat. Apalagi dalam mendidik anak-anak juga sangat diperlukan literasi digital. Tim pengabdi menyampaikan pentingnya menerima informasi berdasarkan berita yang dapat dipercaya. Peserta pengabdian harus mampu memilah berita yang benar adanya dengan berita hoax yang sangat dekat dengan kehidupan masyarakat saat ini. Bahkan masyarakat awam susah membedakan mana berita yang benar dan berita tidak benar informasinya.

Kegiatan pengabdian ini mengajak peserta pengabdian agar tidak menerima informasi hanya dengan satu sumber saja. Mereka harus kreatif dalam menerima kebenaran berita yang ada. Oleh karena itu, diperlukan literasi digital berbasis android dalam kegiatan pengabdian ini. Selain itu, dalam kegiatan pengabdian juga urgensi dengan krisisnya media android yang memiliki fasilitas yang dapat merusak karakter anak-anak. Pada hakikatnya aplikasi yang ada di android sangat mendukung dan membantu kehidupan masyarakat. Namun, jika disalahgunakan bisa menjadi bumerang bagi orang tua dalam mengasuh dan mendidik anak-anak.

Dalam kegiatan berliterasi berbasis android sangat menuntut peran ibu-ibu untuk mengontrol anakanak dalam memakai handphone. Jangan sampai anak-anak yang kita asuh terjermus kepada hal-hal yang negatif. Kegiatan pengabdian mengajak peserta pengabdian agar tidak gabtek dengan teknologi. Penggunaan android untuk meminimalisasi hal-hal yang memperburuk karakter anak-anak. Dalam 
penggunaan android kita harus bijak dalam penggunaannya karena setiap aplikasi yang ada di dalam handphone memiliki manfaat bagi masyarakat penggunanya.

Saat pertemuan kedua dilakukan pada tanggal 16 Desember 2018, kegiatan pengabdian kepada masyarakat ini dilaksanakan oleh 17 orang peserta pengabdian. Pada pertemuan kedua ini, topik materi pengabdian berupa literasi digital, kesantunan berbahasa bagi anak-anak, dan penggunaan aplikasi bahasa Inggris agar mahir berbahasa Inggris. Dalam kegiatan literasi digital kita bisa menerima, memilih, memilah, menelaah, dan menyimpulkan informasi secara optimal. Dalam berliterasi digital juga harus mampu berbahasa secara santun. Kesantunan berbahasa merupakan ciri khas dari bangsa Indonesia khususnya masyarakat di Seroja yang multikultur. Dalam kegiatan ini, tim pengabdi juga menyampaikan pentingnya lestarikan bahasa daerah, utamakan bahasa Indonesia, kuasai bahasa asing.

Sebagai masyarakat yang berbudaya, kita tidak perlu malu dan gengsi dalam menggunakan sembari melestarikan bahasa daerah kita masing-masing. Jangan sampai bahasa daerah kita punah ditangan kita sendiri dalam kehidupan berkeluarga. Alangkah lebih baiknya kita membudayakan bahasa daerah kepada generasi kita. Selain itu, bahasa Indonesia menjadi bahasa pengantar peserta pengabdian untuk bisa berkomunikasi dan berinteraksi secara efektif. Bahasa Indonesia menjadi pemersatu masyarakat yang berlatar belakang budaya berbeda.

Untuk menunjang kemampuan pengauasaan bahasa asing berupa bahasa Inggris sebagai bahasa internasional, maka penggunaan android sebagai media yang sangat diminati oleh masyarakat sekarang khususnya pelajar. Penggunaan android untuk menumbuhkan dan membangun skill anak-anak kita. Tujuannya adalah agar anak-anak mampu berdaya saing jika sudah memiliki kemahiran berbahasa Inggris. Peserta pengabdian yang didominasi oleh ibu-ibu rumah tangga agar mengontrol anak-anak di rumah agar bisa mengawasi yang diakses oleh anak-anak di android nya. Penggunaan aplikasi android ini agar meningkatkan kemampuan anak-anak agar mahir bahasa Inggris.

Tim pengabdi menyampaikan salah satu aplikasi bahasa Inggris yang efektif digunakan adalah duolingo. Saat kegiatan pengabdian kedua ini, terdapat pertanyaan dari peserta pengabdian bagaiaman untuk melacak riwayat apa yang diakses oleh anak-anak. Dalam kegiatan pengabdian, kita sebagai pengguna teknologi harus hati-hati dalam penggunaan media sosial karena bisa dilacak pada database pembuat aplikasinya. Peserta pengabdian juga bertanya bagaimana caranya memblokir aplikasi yang ada pada android anak-anak mereka. Ibu-ibu tersebut merasa resah dengan kecanduan anak-anak mereka akan android. Kegiatan ini disambut positif oleh peserta pengabdian karena topik pengabdian tergolong pada topik kekininan sehingga sangat dibutuhkan oleh masyarakat.

Selain itu, penggunaan media sosial dan android yang ada juga harus membentuk karakter anak. Jangan sampai anak-anak menjadi salah prilaku, bertindak secara kasar, bertutur yang tidak sopan, ataupun pemalu bahkan menghilangkan jati dirinya sebagai kaum laki-laki atau perempuan. Oleh karena itu, diperlukan kebijaksanaan dan ketegasan orang tua dalam mengawasi setiap kegiatan anak-anaknya yang berselancar menggunakan android. Hal ini bertujuan agar tidak merusak cita-cita dan masa depan anak-anak sehingga menjadi geenrasi emas yang maju dan berdaya saing unggul.

Pada pertemuan ketiga dilaksanakan pada tanggal 13 Januari 2019, peserta pengabdian yang datang sebanyak 27 orang. Pada pertemuan tersebut, tim pengabdi membagikan materi kepada peserta pengabdian. Materi yang disampaikan adalah istilah bahasa Inggris bersifat negatif di media sosial yang perlu diketahui oleh orang tua dalam menghadapi era digital ini. Dalam penyampaian materi tersebut, peserta pengabdian terenyuh bahwasanya mereka tidak menyangka ada singkatan-singkatan berbau pornografi yang dapat merusak masa depan anak-anak mereka. Oleh karena itu, kegiatan pengabdian saat urgen dilaksanakan untuk membuka cakrawala dan memperluas imu ngetahuan yang tentunya tepat sasaran sebagai inti dari kegiatan pengabdian kepada masyarakat sehingga membawa manfaat yang positif.

Penyampaian materi ini sangat alot dan intensif diikuti oleh-oleh ibu peserta pengabdian. Mereka berdiskusi dan bertanya jawab kepada tim pengabdi. Selain itu, tim pengabdi juga mengajak ibu-ibu peserta pengabdian agar memulai bahasa Inggris dalam kegiatan sehari-hari walaupun belum mahir. Hal ini bertujuan agar anak-anak mereka termotivasi untuk menggunakan bahasa Inggris sehingga tidak kaku. Tim pengabdi menghimbau agar peserta pengabdian tidak malu dalam berbahasa Inggris walaupun belum 
mahir kepada anak-anaknya. Jika kita belajar tentunya nanti akan menjadi suatu kebiasaan bagi ibu-ibu rumah tangga tersebut dalam mengucapkan

Selanjutnya, pengenalan tahap awal dala penggunaan aplikasi kedua untuk kemahiran berbahasa Inggris. Aplikasi yang dimaksud adalam aplikasi ID EN translator. Pengenalan ini agar untuk pertemuan selanjutnya peserta pengabdian membawa android untuk bisa diinstallkan aplikasi tersebut oleh tim pengabdi. Aplikasi ini memiliki kelebihan untuk bisa menerjemahkan secara tulis maupun lisan. Tulisan dengan maksud mengetik kata-kata sesuai kebutuhan, sedangkan lisan bisa dilakukan dengan cara merekam suara ke dekat aplikasi tersebut. Secara otomatis, aplikasi yang dipakai secara daring ini bisa langsung menerjemahkan sesuai dengan penyampaian si pengguna.

Saat pertemuan keempat dihadiri oleh 29 orang yang dilaksanakan pada tanggal 10 Februari 2019. Pada pertemuan keempat ini, tim pengabdi membantu untuk meng-install kan aplikasi ID EN translator di android peserta pengabdian. Tim pengabdi juga memfasilitasi dalam bentuk pemakaian hotspot pribadi agar peserta pengabdian dapat dengan lancar untuk mengunduh dan mengaksesnya. Kegiatan ini sangat menarik sehingga memperluas pengetahuan peserta pengabdian dalam penggunaannya. Selanjutnya, bisa dipraktikkan pada anak-anak peserta pengabdian di rumah sehingga menunjang kemahiran berbahasa Inggris dan meningkatkan prestasi belajarnya. Penggunaan aplikasi ID EN translator sama dengan aplikasi kamus. Aplikasi ini digunakan secara daring. Aplikasi ini digunakan untuk menerjemahkan katakata maupun kalimat dari bahasa Inggris ke bahasa Indonesia, dan sebaliknya. Tim pengabdi memandu peserta pengabdian untuk membuka play store untuk mengunduh aplikasi ID EN translator. Setelah terpasang di android peserta pengabdian, tim pengabdi mulai mengarahkan pemakaiannya. Aplikasi ini sangat memerikan kemudahan kepada pengguna agar mampu berliterasi berbasis android untuk meningkatkan kemahiran berbahasa Inggris.

Pada pertemuan kelima dilakukan pada tanggal 24 Februari 2019, kegiatan pengabdian kepada masyarakat dihadiri sejumlah 24 orang. Kegiatan ini menjadi kegiatan penutup dalam kegiatan pengabdian kepada masyarakat. Penyampaian materi disampaikan oleh mahasiswa sebagai anggota tim pengabdi. Mahasiswa dilatih agar mampu beradaptasi di kehidupan masyarakat sebelum mereka lulus kuliah. Hal ini menjadi nilai unggul bagi institusi karena melibatkan mahasiswa pada kegiatan tri darma perguruan dosen.

Pada kegiatan ini, tim pengabdi menyampaikan agar mampu berliterasi dan melihat histori android yang diakses oleh anak-anak mereka di rumah. Selain itu, tim pengabdi juga mempraktikkan untuk memblock aplikasi yang sangat merusak bagi anak-anak. Aplikasi yang disampaikan bernama block shite. Peserta pengabdian sebagai ibu-ibu rumah tangga perlu mengontrol dan mengawasi anak-anaknya dalam pemakaian akses yang dilakukannya. Kegiatan ini juga bisa melacak riwayat pada media soaial berupa facebook, whatsapp, instagram, dll. Tim pengabdi menghampiri peserta pengabdian untuk memandu pemakaian aplikasi. Tujuan penyampaian materi ini agar peserta pengabdian bisa mengecek dan menghapus konten-konten pornografi atau hal-hal negatif yang dapat merusak dan menurunkan prestasi belajar anak-anak. Tim pengabdi memastikan satu persatu peserta pengabdian apakah sudah memahami dan mampu menggunakan aplikasi yang sudah diunduh.

Selanjutnya, pemantapan dalam penggunaan aplikasi duo linggo. Ternyata sejak pengenalan aplikasi tersebut pada pertemuan kedua, sebagian peserta pengabdian sudah mulai mengunduh dan menggunakannya.mereka berpendapat bahwa aplikasi sangat menarik dan sangat membantu kemahiran berbahasa Inggrisnya serta anak-anak mareka di rumah. Aplikasi ini juga dilengkapi oleh fitur suara, game, gambar yang menarik sehingga memotivasi kemahiran berbhasa Inggris pengguna. Oleh karena itu, kegiatan pengabdian ini terlaksana dengan lancar dan efektif selama lima kali pertemuan.

Pembahasan pada kegiatan pengabdian bermuara dari masalah dan fenomena yang diperoleh tim pengabdi saat observasi sebelum kegiatan pengabdian berlangsung. Berdasarkan fenomena tersebut, pengabdian kepada masyarakat ini sangat urgen dilaksanakan sehingga juga memeroleh dukungan dan partisiasi dari mitra beserta peserta pengabdian di Seroja Kecamatan Sagulung Kota Batam. Kegiatan pengabdian ini memiliki urgensi untuk memerikan perubahan dan peningkatan tentang kemahiran berbahasa Inggris kepada masyarakat. Termasuk pada pengoptimalisasikan android sebagai sarana yang efektif bagi masyarakat. Selain itu, kegiatan pengabdian ini untuk mengubah karakter masyarakat menjadi 
pribadi yang lebih baik lagi. Berikut dijabarkan secara spesifikasi pembahasan kegiatan pengabdian dengan topik Pembinaan Budaya Literasi Berbasis Android untuk Kemahiran Bahasa Inggris dan Kesantunan Berbahasa Melalui Pendidikan Berkarakter Masyarakat Dapur 12 Batam.

Pertama, awal mula masyarakat belum mengetahui tentang literasi padahal literasi sebagai pondasi dasar bagi masyarakat untuk bisa mengetahui, menerima, menyadur, dan menganalisis tentang suatu perkara atau informasi yang belum jelas kebenaraanya. Pada saat kegiatan pengabdian, sebagai pertemuan awal masyarakat diberikan pengantar seputar literasi. Kegiatan berliterasi sangat menguntungkan bagi masyarakat agar tidak mudah dipengaruhi oleh informasi yang tidak bisa dipertanggungjawabkan kebenarannya. Bahkan dengan literasi, masyarakat memeroleh ilmu pengetahuan dan wawasan seputar perkembangan teknologi yang begitu pesat hingga saat ini.

Kedua, berdasarkan masalah yang diperoleh bahwa masyarakat gampang terpengaruh akan berita hoax. Masyarakat Seroja sebagai peserta pengabdian berupaya untuk menangkal hoax yang kian hari merajalela. Masyarakat diminta untuk tidak terpengaruh berita hoax baik seputar ras, agama, suku, dan politik. Masyarakat diajak agar cerdas dan bijak dalam menerima informasi apapun. Masyarakat Seroja harus mengutamakan kekompakkan untuk memupuk persatuan dan kesatuan antarsesama warga masyarakat.

Ketiga, masyarakat Seroja sebagai peserta pengabdian sudah cakap akan teknologi. Bahkan setiap peserta sudah mahir menggunakan android yang dimilikinya. Namun, sebagian dari mereka belum mengetahui kegunaan dan keuntungan dari setiap aplikasi yang ada pada android nya. Oleh karena itu, tim pengabdi berupaya untuk mengenalkan setiap aplikasi yang ada serta aplikasi yang cocok untuk belajar kemahiran berbasa Inggris. Selain itu, tim pengabdi juga membantu untuk pengunduhan aplikasi bahasa Inggris serta penjelasannya secara detail. Bahkan masyarakat langsung praktik bersama tim pengabdi.

Keempat, sesuai informasi yang diperoleh bahwa masyarakat belum mengetahui terjemahan kata demi kata pada bahasa Inggris. Dengan kegiatan pengabdian ini, masyarakat dikenalkan dengan aplikasi ID EN translator dan duo linggo. Masyarakat sangat antusias dan bertanya jawab seputar penggunaan aplikasi yang membantu mereka ini untuk memahami bahasa Inggris sehingga juga bisa membantu anakanaknya dalam berbahasa Inggris di rumah. Ibu-ibu sebagai peserta pengabdian menjadi anutan yang baik bagi anak-anaknya di rumah untuk memacu kecakapan dan kemahiran berbahasa Inggris anak mereka. Dengan kegiatan pengabdian kepada masyarakat ini, juga berpeluang agar peserta pengabdian bisa membuka tempat les atau bimbingan belajar bahasa Inggris.

Kelima, tim pengabdi pada saat kegiatan pengabdian mengemukakan sebuah kasus seputar karakter. Karakter menjadi bagian terpenting untuk bisa bersosialisasi secara santun dengan anggota keluarga, masyarakat, dan di lingkungan sekolah. Pendidikan karakter yang dimaksud adalah kesantunan berbahasa. Pada saat penyampaian materi, tim pengabdi menyampaikan pentingnya kesantunan berbahasa. Apalagi bahasa dianggap sebelah mata oleh sebagian warga masyarakat. Tim pengabdi menumbuhkan agar peserta pengabdian juga memerikan pola didikan yang baik dan berkarakter kepada anak-anak mereka di rumah. Peserta pengabdian harus berani menyampaikan secara jujur bahwa ini salah maupun benar degan segala konsekuensi yang ada.

Keenam, pendayagunaan literasi berbasis android ini dapat memerikan dampak positif kepada masyarakat agar masyarakat terhindar dari hal-hal yang provokatif maupun penipuan online yang marak terjadi. Melalui kegiatan pengabdian ini, masyarakat juga mampu bersikap kritis dan mampu mengubah pola pikir. Masyarakat tidak terpedaya dan terkecoh dengan informasi promo-promo suatu produk secara online, lowongan pekerjaan, maupun bonus-bonus dari sebuah produk yang terlihat menjanjikan dan menyakinkan. Hal ini akan membawa keutungan kepada masyarakat sehingga masyarakat terhindar dari hal-hal yang dapat menggangu dan merusak kelangsungan hidup mereka. Di samping itu, kehidupan masyarakat juga terjaga dengan aman dan kondusif.

Kegiatan pengabdian kepada masyarakat ini, dilaksanakan secara efektif selama dua jam setiap kali pertemuan. Kegiatan ini snagat disambut secara positif oleh warga sebagai peserta pengabdian termasuk juga unsur RT dan RW setempat. Pihak mitra menyampaikan terima kasih dengan adanya kegiatan pengabdian membawa perubahan dan kontribusi masyarakat Seroja. Peserta pengabdian mengetahui dan 
siap dengan kegiatan berliterasi. Oleh karena itu, kegiatan pengabdian kepada masyarakat membawa manfaat yang sangat kontibutif bagi peserta pengabdian. Bahwasanya kegiatan pengabdian untuk mengoptimalkan budaya literasi berbasis android untuk meningkatkan kemahiran berbahasa Inggris dan kesantunan berbahasa masyarakat yang positif bagi melalui pendidikan berkarakter.

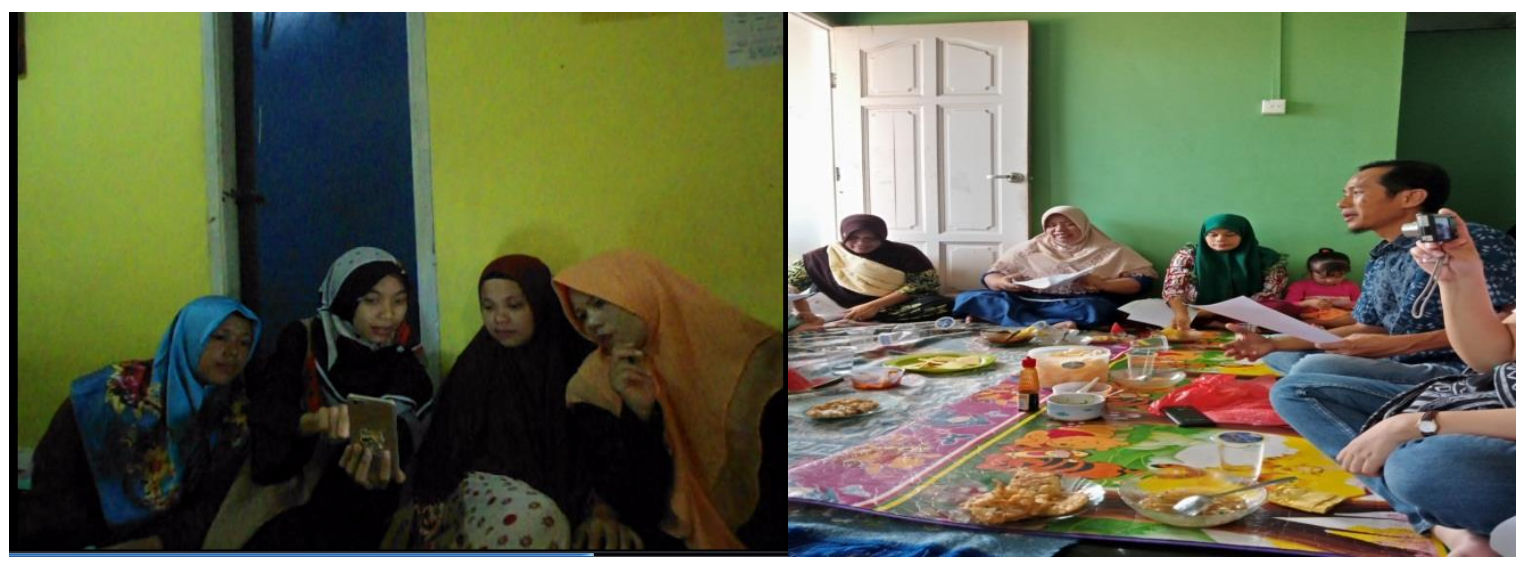

Gambar 1 Pengabdian

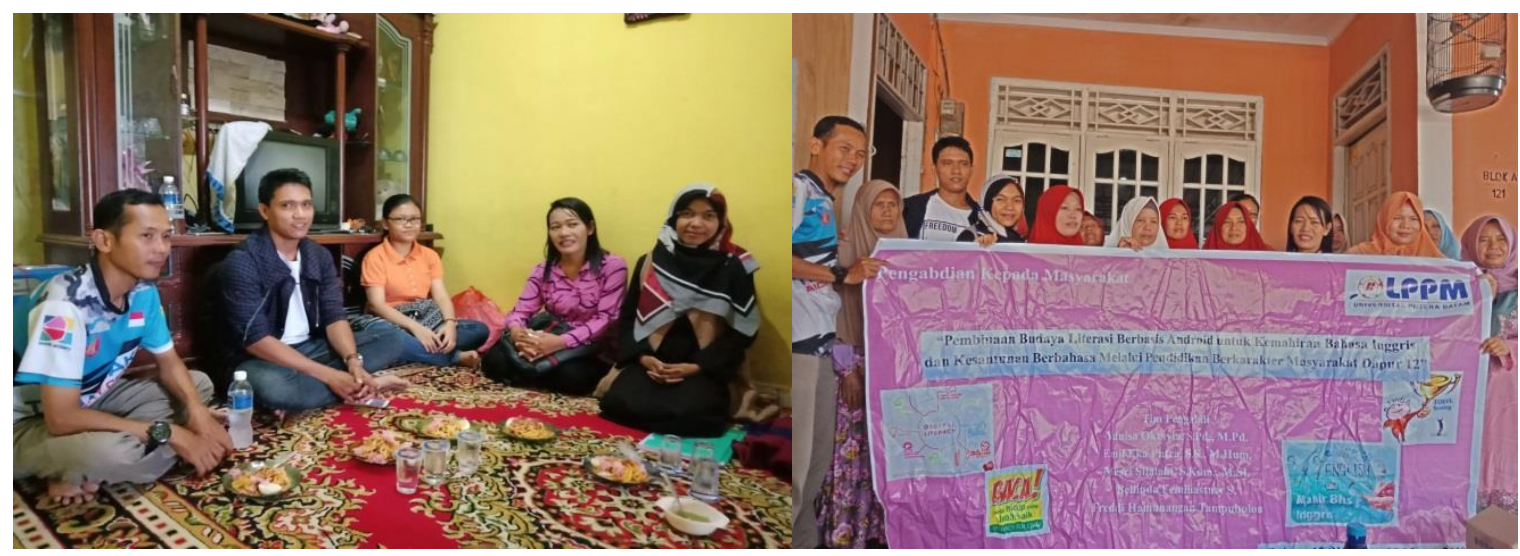

Gambar 2 Pengabdian

\section{SIMPULAN}

Kegiatan pengabdian ini dilaksanakan selama lima kali pertemuan yang dimulai pada tanggal 2 Desember 2018 sampai 24 Februari 2019. Tema kegiatan pengabdian ini adalah Pembinaan Budaya Literasi Berbasis Android untuk Kemahiran Bahasa Inggris dan Kesantunan Berbahasa Melalui Pendidikan Berkarakter Masyarakat Dapur 12 Batam. Kegiatan pengabdian ini bertujuan untuk mengoptimalisasikan budaya literasi berbasis android untuk meningkatkan kemahiran berbahasa Inggris dan kesantunan berbahasa melalui pendidikan berkarakter masyarakat. Kegiatan pengabdian ini memiliki urgensi untuk memerikan perubahan dan peningkatan tentang kemahiran berbahasa Inggris kepada masyarakat. Termasuk pada pengoptimalisasikan android sebagai sarana yang efektif bagi masyarakat. Selain itu, kegiatan pengabdian ini untuk mengubah karakter masyarakat menjadi pribadi yang lebih baik lagi. Kegiatan pengabdian kepada masyarakat ini sebagai ajang untuk sharing dan saling berbagi informasi kepada peserta pengabdian bahwa budaya literasi itu sangat penting. Peserta pengabdian tidak boleh terhasut dan diprovokasi oleh informasi yang belum tentu kebenarannya sehingga tidak bisa dipertanggungjawabkan. Di samping itu, kegiatan berliterasi untuk menghindari terjadinya kesalahpahaman sesama anggota masyarakat berbau SARA dan politisasi tidak sehat. Masyarakat harus mampu memfilter hoax, tidak terperdaya dengan promo-promo online suatu produk serta tidak tergoda 
dengan pekerjaan yang dipromosikan secara online dengan gaji menarik yang sangat marak terjadi pada masa kini. Selain itu, peserta pengabdian juga diajak agak mampu berliterasi digital. kegiatan pengabdian untuk mengoptimalkan budaya literasi berbasis android untuk meningkatkan kemahiran berbahasa Inggris dan kesantunan berbahasa masyarakat melalui pendidikan berkarakter.

\section{SARAN}

Setelah kegiatan berlangsung selama lima kali pertemuan dikemukakan saran sebagai berikut.

1. Kegiatan pengabdian ini memerlukan alat dan teknologi pendukung berupa infocus sehingga bisa menayangkan slide materi secara efektif dan efisien.

2. Peserta pengabdian sebaiknya membawa alat komunikasi berupa android yang mereka miliki agar pengarahan dan penyampaian materi lebih tepat sasaran saat praktik berlangsung.

3. Pada kegiatan selanjutnya, jika pengabdian berlanjut maka sebaiknya anak-anak peserta pengabdian secara keseluruhan juga ikut serta agar penyampaian materi dapat dilaksanakan secara maksimal baik kepada ibunya maupun kepada anak-anaknya.

\section{UCAPAN TERIMA KASIH}

Penulis mengucapkan terima kasih kepada Universitas Putera Batam yang telah memerikan dukungan finansial terhadap kegiatan pengabdian kepada masyarakat ini.

\section{DAFTAR PUSTAKA}

[1] Akhyar, Y. L, 2017, Ngebahas Cyber Culture. An1magine, Vol 2 No 8, 69.

[2] Muslich, M, 2011, Pendidikan Karakter: Menjawab Tantangan Krisis Multidimensional, Bumi Aksara, Jakarta.

[3] Tirado-Morueta, R., Aguaded-Gómez, J. I., \& Hernando-Gómez, Á, 2018, The socio-demographic divide in Internet usage moderated by digital literacy support. Technology in Society, March 2017, 19. https://doi.org/10.1016/j.techsoc.2018.06.001

[4] Oktavia, Y., Hulu, F., \& Batam, U. P, 2017, Pengembangan Modul Ejaan Bahasa Indonesia Berbasis Pendekatan Contextual Teaching and Learning Bermuatan Pendidikan Karakter, Pengembangan Modul Ejaan, Halaman, 2(2), 250-265. 